\title{
Chemoprophylaxis for babesiosis and anaplasmosis in cattle: case report
}

\author{
Quimioprofilaxia para babesiose e anaplasmose em bovinos: relato de caso
}

\author{
Jerbeson Hoffmann da Silva'; Renata Rebesquini²; Diorges Henrique Setim³; \\ Cláudia Almeida Scariot3; Maria Isabel Botelho Vieira ${ }^{3 *}$ (D); Ricardo Zanella3; Adriana Costa da Motta3; \\ Leonardo Porto Alves ${ }^{1}$; Carlos Bondan ${ }^{1,3}$
}
${ }_{1}^{1}$ Programa de Residência Profissional Integrada em Medicina Veterinária, Universidade de Passo Fundo - UPF, Passo Fundo, RS, Brasil
${ }^{2}$ Programa de Pós-graduação em Agronomia, Universidade de Passo Fundo - UPF, Passo Fundo, RS, Brasil
${ }^{3}$ Programa de Pós-graduação em Bioexperimentação, Universidade de Passo Fundo - UPF, Passo Fundo, RS, Brasil

How to cite: Silva JH, Rebesquini R, Setim DH, Scariot CA, Vieira MIB, Zanella R, et al. Chemoprophylaxis for babesiosis and anaplasmosis in cattle: case report. Braz J Vet Parasitol 2020; 29(4): e010520. https://doi.org/10.1590/S1984-29612020096

\begin{abstract}
Cattle tick fever (CTF) causes significant economic losses in the livestock sector. The pathogenic action of the hemoparasites is associated with anemia, weight loss, abortion and reduced productivity, which result with animal death. Programs to prevent CTF involve several procedures, including immunization, chemoprophylaxis and use of ectoparasiticides, together with the vector control in the environment. The objective of this study was to report an acute outbreak of CTF in a group of 157 Hereford cattle from a farm without presence of the vector, that were moved to a farm in the same state with a high tick infestation (Rhipicephalus microplus). On the day before the transportation, the animals received a chemoprophylaxis with imidocarb dipropionate (3 mg/ $/ \mathrm{kg}, \mathrm{SC})$, which was repeated 21 days after the first application. After 42 days, some animals showed signs compatible with CTF, which was confirmed through clinical examination, necropsy, histopathological and hemoparasitological analyses. The morbidity rate was $37.6 \%$ and the mortality rate was $24.8 \%$. Calves that were recently weaned were the group most affected with the tick fever, morbidity (100\% and mortality (73\%). Chemoprophylaxis in association with use of ectoparasiticides was not sufficient to control the outbreak of the disease.
\end{abstract}

Keywords: Prevention, imidocarb, cattle tick fever.

\section{Resumo}

A "tristeza parasitária bovina" (TPB) gera importantes perdas econômicas na bovinocultura mundial. A ação patogênica dos hemoparasitas resulta em anemia, perda de peso, abortos e diminuição da produtividade, culminando, muitas vezes, em óbito dos animais. Um programa de prevenção para TPB necessita de medidas integradas, como a imunização, quimioprofilaxia e utilização de ectoparasiticidas, em conjunto com ações que visem ao controle ambiental dos vetores. Este artigo tem em vista o relato de um surto de TPB em uma fazenda de produção de bovinos de corte e com alta infestação do carrapato (Rhipicephalus microp/us). A fazenda adquiriu 157 animais puros de origem, da raça Hereford, proveniente de uma fazenda sem presença do vetor. No dia anterior ao transporte, os animais receberam quimioprofilaxia com dipropionato de imidocarb ( $3 \mathrm{mg} / \mathrm{Kg} / \mathrm{SC}$ ), repetindo-se 21 dias após a primeira aplicação. Aos 42 dias, alguns bezerros manifestaram sinais clínicos compatíveis com TPB, sendo confirmado pelo exame clínico, necropsia, análises histopatológicas e hemoparasitológicas. A morbidade foi de $37,6 \%$ (59/157), e a letalidade de $24,8 \%$ (39/157). A categoria de bezerros recém desmamados foi a mais acometida, com morbidade de 100\% (52/52) e letalidade de $73 \%$ (38/52). A quimioprofilaxia associada à utilização de ectoparasiticidas foram insuficientes para evitar a ocorrência do surto da enfermidade.

Palavras-chave: Prevenção, imidocarb, tristeza parasitária bovina. 


\section{Introduction}

Cattle tick fever (CTF) is a complex of diseases affecting cattle worldwide (Gonçalves, 2000). CTF is cause by the Rickettsia Anaplasma marginale (bovine anaplasmosis) and the protozoa Babesia bovis and Babesia bigemina (bovine babesiosis) (Grau et al., 2013; Souza et al., 2018). The cattle tick Rhipicephalus microplus is the main vector involved with the transmission of CTF and is the only known vector for bovine babesiosis (Souza et al., 2018). Bovine anaplasmosis can also be transmitted mechanically by hematophagous dipterans (Stomoxys calcitrans, tabanids and culicids), via iatrogenic and transplacental routes (Grau et al., 2013).

Geographical regions with significant annual variations in populations of $R$. microplus are more favorable for the occurrences of CTF outbreaks (Souza et al., 2018) when compared with regions in which the presence of this vector is stable (Brito et al., 2013). Cattle from enzootically unstable tick areas are more susceptible, since the absence of contact with the pathogens implies in the absence of immunity against the disease (Schild et al., 2008). Therefore, it is very important to know the epidemiology of the vectors in each region.

In the southern region of Brazil, the tick cycle consists of three generations, such that the first occurs in the southern hemisphere spring (a period of low infestation), the second in the summer and the third in the autumn (high infestation) (Vieira et al., 2002). Tick control using acaricides should start in the spring, when infestation is at its lowest, thus diminishing the tick population in the environment (Martins et al., 2002). On the plateau of the Santa Catarina state, Brazil, from January to April is the period with higher tick infestation and from August to November is the lowest, which is also associated with summer and winter seasons (Souza et al., 1988).

Together with integrated control of vectors, the use of vaccination and chemoprophylaxis is also recommended (Suarez \& Noh, 2011). Immunization uses attenuated live strains of B. bovis, B. bigemina, A. marginale and A. centrale, to promote cross-immunity against $A$. marginale. Thus, molecular technologies using the purified outer membrane of $A$. marginale have shown some effectiveness with regard to induction of protective immunity (Suarez \& Noh, 2011). Chemoprophylaxis consists of use of imidocarb dipropionate, which has a prophylactic effect (1-2 mg/kg) or a therapeutic effect (4-5 mg/kg) against $B$. bovis and $B$. bigemina. Its use eliminates or prevents infection by these hematozoa and, as the plasma concentration decreases, gradual development of parasitemia takes place. This allows the animals to develop their own immunity, without any occurrence of clinical cases (Kuttler \& Johnson, 1986; de Vos et al., 1986; Vial \& Gorenflot, 2006).

The objective of the present study was to describe an outbreak of babesiosis and anaplasmosis in purebred Hereford cattle herd in the city of Painel located in the Santa Catarina state, after chemoprophylaxis.

\section{Materials and Methods}

A farm located in the city of Painel, Santa Catarina state (farm A), acquired a total of 157 Hereford cattle (99 cows, 6 bulls and 52 recently weaned calves). They came from a single farm located in the city of Água Doce, also in the state of Santa Catarina (farm B). Farm A presented a high infestation with the tick $R$. microplus, while farm B was considered an enzootically unstable area for $R$. microplus.

Because of the high incidence of ticks on farm $A$, it was suggested to implement a tick control measures among these 157 animals, which consisted of chemoprophylaxis using imidocarb dipropionate $(3 \mathrm{mg} / \mathrm{kg}, \mathrm{SC})$ and vector control using an association of fluazuron $(2.5 \mathrm{mg} / \mathrm{kg})$, cypermethrin $(5 \mathrm{mg} / \mathrm{kg})$, chlorpyrifos $(7 \mathrm{mg} / \mathrm{kg}$ ) and citronella $(0.5 \mathrm{mg} / \mathrm{kg})$, which was administered as a pour-on treatment, one day before the animals arrived in farm A.

Twenty-one days after the animals been introduced on farm A, all of them presented infestation with $R$. microplus. On this day, it was decided to use a second administration of imidocarb dipropionate, at the same dosage via SC.

Forty-two days after the animals been on farm A, 52 calves, 4 cows and three bulls presented apathy, anorexia or hyporexia, fever, pallid/jaundiced mucosa, ruminal atony, tachycardia, tachypnea, weight loss and goosebumps. Some of these animals presented a fast progression of their condition, to prostration, pedaling movements and death. The animals that showed clinical signs were treated with diminazene diaceturate $(3.5 \mathrm{mg} / \mathrm{kg}, \mathrm{IM})$ and oxytetracycline (20 mg/kg, IM), both as a single dose.

A team of veterinarians from the University of Passo Fundo visited farm A and observed that the clinical signs were compatible with hemoparasitosis. To confirm the diagnosis, whole peripheral blood was collected from 15 calves and 25 adult cows. Among these, only the calves presented clinical symptoms. The blood samples were collected through venous puncture under vacuum, using $2 \mathrm{~mL}$ tubes containing EDTA. Each blood sample was evaluated in microcapillary tubes in duplicate after centrifugation for five minutes at 10,000g using an appropriate microcapillary 
tube centrifuge (DHM_6, Benfer ${ }^{\circledR}$ ). The total plasma protein (TPP) was determined using the refractometry technique (Instrutherm $\left.{ }^{\circledR}\right)$, using the plasma that were obtained through centrifugation. Peripheral blood was also collected from the ear tip in order to produce blood smears. Slides were prepared and stained on-site, using Diff-Quick staining, and these were sent for investigation of hemoparasites in the Animal Pathology Laboratory of the University of Passo Fundo (UPF).

Two calves that died on the day of the visit were necropsied, and fragments of all their organs were collected and fixed in $10 \%$ buffered formalin, for histopathological analysis in the Animal Pathology Sector of UPF. The samples were sectioned and routinely processed for histological analysis with hematoxylin-eosin (H\&E) staining. Fragments of telencephalon, liver and kidney were stained with Toluidine Blue (TBO).

\section{Results}

Only the animals that came from farm B became ill. In total, one bull and 38 calves died. The morbidity rate was $37.6 \%$ (59/157) and the mortality rate was $24.8 \%$ (39/157). Among these animals, the most affected group was the calves, where the morbidity rate was $100 \%$ (52/52) and the mortality rate was $73 \%$ (38/52).

Blood samples were collected from a total of 15 calves and 25 adult cows. Whole peripheral blood was used to determine the packed cell volume (PCV), and peripheral blood from the ear tip was used to produce blood smears. The mean PCV levels among the calves was $19 \pm 5.4 \%$ and the mean TPP was $6.5 \pm 1.8 \mathrm{~g} / \mathrm{dL}$. Among the adult cows, the mean PCV was $22.6 \pm 7.4 \%$ and the mean TPP was $6.1 \pm 0.9 \mathrm{~g} / \mathrm{dL}$. From the blood smears, seven samples were positive for A. marginale (17.5\%) (Figure 1), seven were positive for B. bovis (17.5\%) and eleven were positive for A. marginale and $B$. bovis (27.5\%). In total, 25 animals (62.5\%) had a confirmed hemoparasitological diagnosis of CTF.

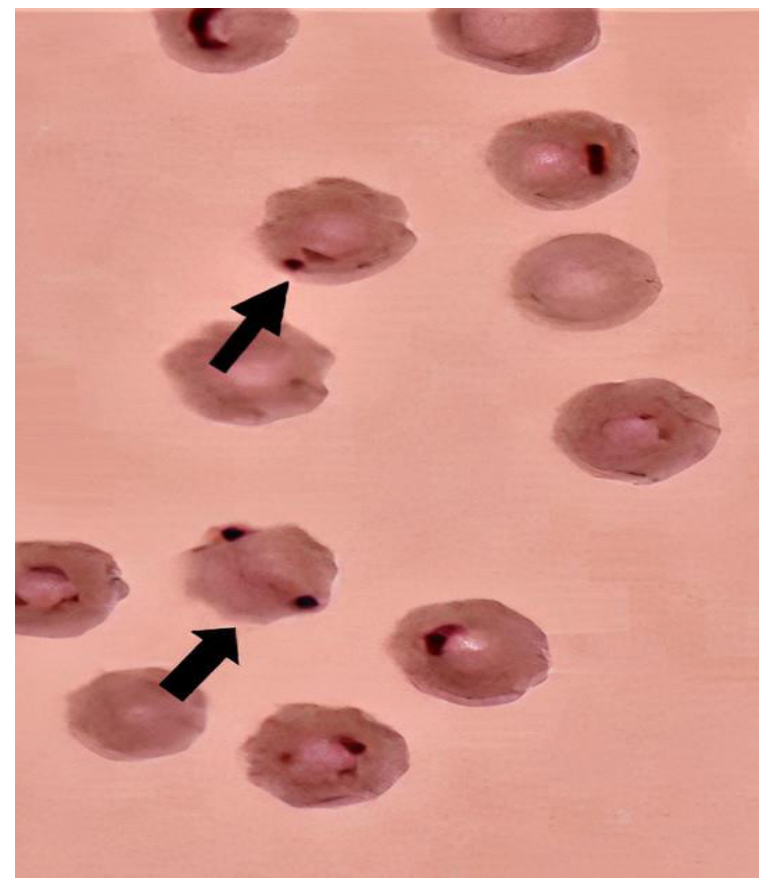

Figure 1. Black arrows are showing the Anaplasma marginale in blood smears.

Among the gross findings from the necropsies on the two calves, the following were seen: pallid carcass, hepatosplenomegaly, gallbladder full of lumpy bile, kidneys with a dark red capsular surface and parenchyma, hydropericardium, encephalic surface (Figure 2a) and gray matter of the brain showing cherry-pink color (Figure 2b). The histopathological findings showed centrolobular to midzonal hepatocellular necrosis, with slight multifocal congestion; kidneys with areas of congestion in the vessels of the distal tubules; diffuse tubular necrosis; and a spleen with depletion of the white and red pulp and presence of hemosiderin. Telencephalon sections stained with TBO allowing a better visualization of one or two rounded-shaped organisms within the erythrocyte which is compatible with B. bovis infection (Figure 2c). 


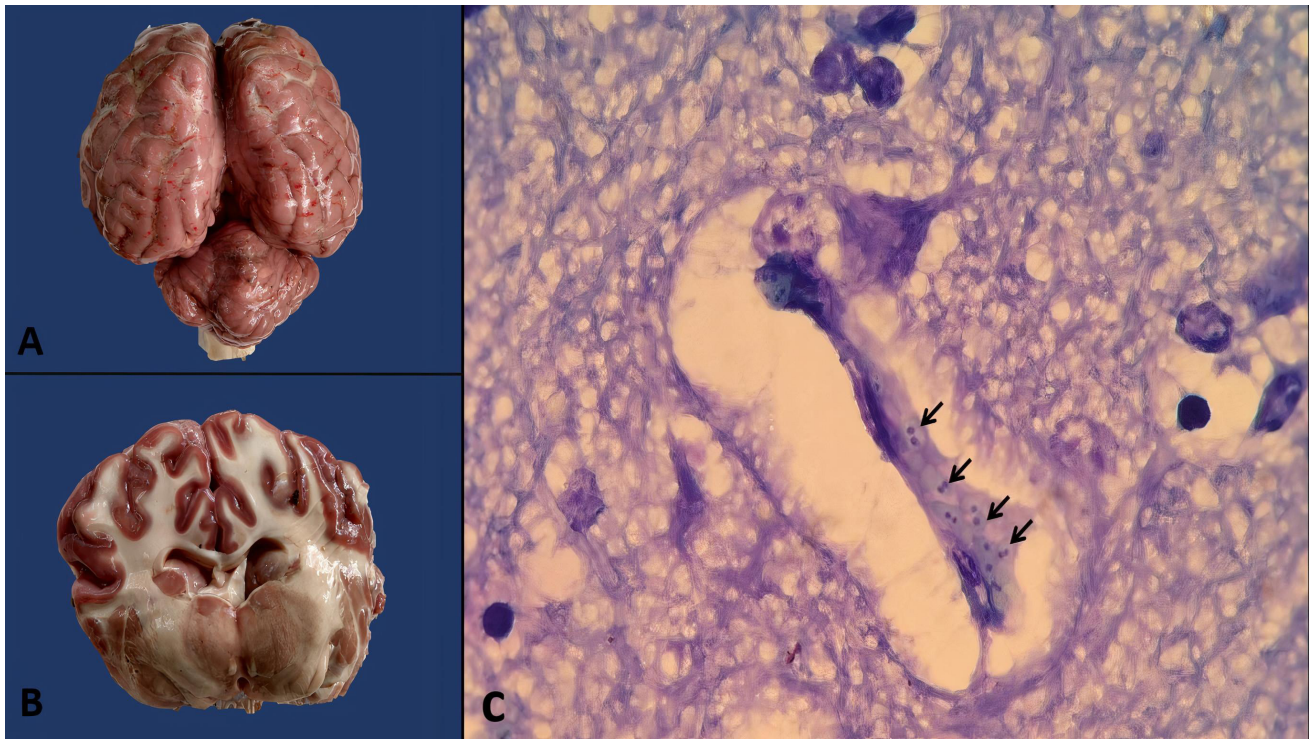

Figure 2. (a) Encephalic surface showing cherry-pink color; (b) Telencephalon sections showing cherry-pink color in the cortex; (c) Telencephalon: capillary in the cortex filled with red blood cells containing intra-erythrocyte structures compatible with Babesia bovis. Toluidine Blue staining,100X.

\section{Discussion}

The diagnosis of CTF was obtained through epidemiological data, clinical signs, identification of hemoparasites in peripheral blood, clinical pathological assessment, necropsy and histopathological evaluation, with the aim of ruling out other possible causes of death.

Knowledge of the epidemiology of the cattle tick R. microplus is fundamental to outline programs to control and to prevent CTF. Existence of seasonal variations in cattle tick populations is an important factor that is associated with the occurrences of outbreaks. The largest part of Brazilian territory is considered of enzootic stability, without significant variations in tick populations throughout the year (Souza et al., 2018).

In southern Brazil, tick populations vary considerably during the year, therefore it is enzootic unstable (Martins et al., 2002; Vieira et al., 2002). Absence of contact with the vectors at a younger age, may predispose to development of acute clinical signals, which are associated with high mortality rates. In addition, there are multiple genetically distinct strains of these pathogens, and outbreaks can occur even when animals are from geographical areas with the presence of vectors (Lau et al., 2010).

The outbreak of CTF reported here occurred in the fall during the third population peak of the tick $R$. microplus: the time when the highest infestation levels should be observed among the cattle (Souza et al., 1988; Vieira et al., 2002). In strategic tick control programs, it is recommended the use of acaricides in the spring, at the time of lowest population numbers of the tick $R$. microplus. This makes it easier to control them and reduce the tick population density in the environment (Martins et al., 2002).

The resistance of $R$. microplus to the acaricides is constantly increasing on the state of Santa Catarina plateau (Veiga et al., 2012). Therefore it is essential to test the susceptibility of the $R$. microplus strain in order to choose the most appropriate acaricides, since mechanisms of resistance to all classes of available acaricides are widespread in tick populations (Guerrero et al., 2012). Historically, indiscriminate use of chemical compounds has contributed to selection of $R$. microplus tick populations that are resistant to different classes of acaricides in the state of Rio Grande do Sul, such as cypermethrin, chlorpyrifos, amitraz, fipronil and ivermectin (Reck et al., 2014; Klafke et al., 2017).

Farm A historically presented high infestation with $R$. microplus, and control measures were only implemented when the animals presented high levels of infestation, which were corroborated by high levels of infestation in the environment, no susceptibility tests were conducted on the farm.

Thus, even after use of acaricides, the animals that were introduced into this new environment presented high levels of infestation 21 days later. This showed that the combination of acaricides and doses that was used was insufficient for controlling the infestation over time. This three-week period corresponded to the mean duration of the parasitic phase of the cattle tick R. microplus (Souza et al., 1988; Vieira et al., 2002), thus enabling inoculation of pathogens. 
This period of 21 days between arrival and detection of infestation, by visualization of adult forms, coincides with the minimum time to complete the life cycle of $R$. microplus. After 42 days of arrival ( 21 days after infestation was perceived), animals started to present clinical signal compatible with anaplasmosis, as described before. These three weeks period coincides to the incubation period of $A$. marginale (Grau et al., 2013). On the other hand, $B$. bovis presents an incubation period of 6 to 12 days and can by inoculated by the larval forms of $R$. microplus. Maybe animals only became ill after day 42 , because it coincides with the decrease of the chemoprophylactic action of imidocarb dipropionate (Kuttler \& Johnson, 1986).

The animals that were most parasitized were the Hereford cattle that had recently been introduced to this farm. In contrast, the animals that were native to the farm, which were mostly crossbred cattle, presented considerably lower levels of the tick $R$. microplus, thus demonstrating a difference in susceptibility among the animals (Benavides \& Sacco, 2007).

Interestingly, in our study young animals were the most affected, with $100 \%$ morbidity (52/52) and $73 \%$ mortality (38/52). In adult animals, morbidity was $6.66 \%(7 / 105)$ and mortality was $0.95 \%(1 / 105)$.

According to Grau et al. (2013), young animals are less susceptible to hemoparasitosis due to the greater effectiveness of their innate immune system, associated with their acquisition of passive immunity through colostrum, which allows controlled parasitemia and consequent development of an immune response without occurrence of clinical cases. In this case, there was no passive immunization via colostrum, due to absence of previous contact with the vector tick; together with possible impairment of the immune response, due to a set of factors that included weaning, transportation, environmental change and high parasite level with hyperinoculation of hemoparasites.

Imidocarb dipropionate has either chemoprophylactic action (dose of 1-2 mg/kg) or therapeutic action (dose of 4-5 mg/ $\mathrm{kg}$ ) against $B$. bovis and B. bigemina (Kuttler \& Johnson, 1986). Its half-life in plasma ranges from three to six weeks (de Vos et al., 1986; Vial \& Gorenflot, 2006). After three weeks, the circulating levels start to gradually decrease, which allows controlled development of parasitemia and, thus, formation of immunity against the pathogenic agents, without developing the illness (Vial \& Gorenflot, 2006).

Under the conditions of farm $\mathrm{A}$, it is likely that an imbalance occurred between infestation by $R$. microplus (the vector of CTF) and the minimum inhibitory concentration of the chemoprophylaxis, which resulted in development of the clinical disease. This suspicion is reinforced by the fact that on day 42 , when the clinical manifestations began, the animals presented high infestation with $R$. microplus and a decline in the minimum inhibitory concentration of the second dose of imidocarb dipropionate, while the animals' natural defenses were insufficient to contain the parasitemia (Figure 3). According to Vial \& Gorenflot (2006), imidocarb dipropionate presents prophylactic action for 21 days and, therefore, the two administrations with an interval of 21 days between them would maintain protective levels for 42 days. This would also explain the time taken for clinical manifestations to appear.

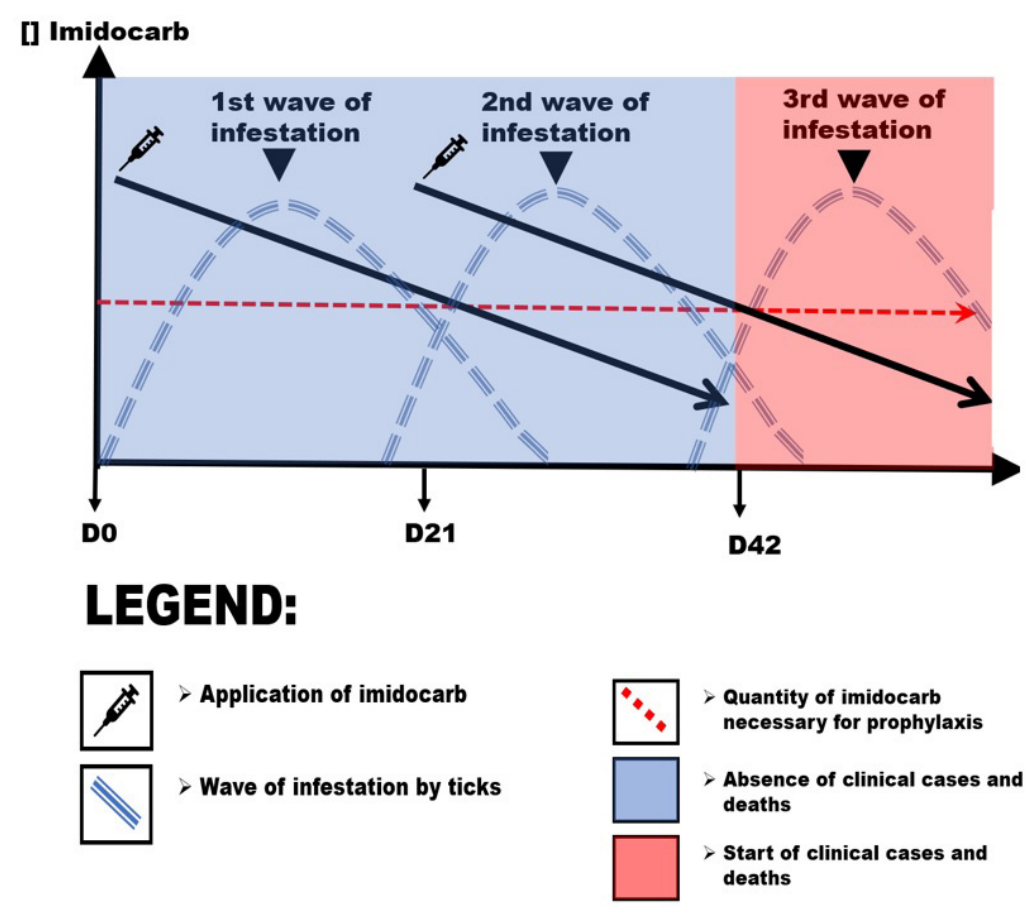

Figure 3. Representation of the relationship between chemoprophylaxis, parasitism by the tick Rhipicephalus microplus and the start of clinical cases of bovine anaplasmosis and babesiosis. 
The clinical cases arose through a combination of factors, including high infestation by the vector (R. microplus), elevated hemoparasitemia, diminished minimum inhibitory concentrations of the chemoprophylactic agent and characteristics inherent to the animals involved, such as breed, phenotype, nutrition, and environment (Benavides \& Sacco, 2007; Adjou Moumouni et al., 2018).

\section{Conclusion}

Knowledge of the epidemiology of the cattle tick R. microplus is important for drawing up control programs for this vector and the diseases associated with it. Success from the therapeutic protocols indicated for prevention of cattle tick disease will only be achieved if exposure to the causal agent occurs in a gradual and controlled manner. For this, knowledge of the sensitivity of vectors to acaricides should be obtained, so as to use these acaricides strategically for controlling the tick population in the environment and on the animals. Only through doing this will chemoprophylaxis fulfill its purpose of avoiding the clinical form of the disease and stimulating the immunological system to develop defenses against diseases.

\section{References}

Adjou Moumouni PF, Aplogan GL, Katahira H, Gao Y, Guo H, Efstratiou A, et al. Prevalence, risk factors, and genetic diversity of veterinary important tick-borne pathogens in cattle from Rhipicephalus microplus-invaded and non-invaded areas of Benin. Ticks Tick Borne Dis 2018; 9(3): 450-464. http://dx.doi.org/10.1016/j.ttbdis.2017.12.015. PMid:29307783.

Benavides MV, Sacco AMS. Differential Bos taurus cattle response to Babesia bovis infection. Vet Parasitol 2007; 150(1-2): 54-64. http://dx.doi.org/10.1016/j.vetpar.2007.08.022. PMid:17919816.

Brito LG, Rocha RB, Barbieri FS, Ribeiro ES, Vendrami FB, Souza GCR, et al. Babesia bovis infection in cattle in the southwestern Brazilian Amazon. Ticks Tick Borne Dis 2013; 4(1-2): 78-82. http://dx.doi.org/10.1016/j.ttbdis.2012.08.001. PMid:23312480.

de Vos AJ, Dalgliesh RJ, McGregor W. Effect of imidocarb dipropionate prophylaxis on the infectivity and immunogenicity of a Babesia bovis vaccine in cattle. Aust Vet J 1986; 63(6): 174-178. http://dx.doi.org/10.1111/j.1751-0813.1986.tb02967.x. PMid:3767795.

Gonçalves PM. Epidemiologia e controle da tristeza parasitária bovina na região sudeste do Brasil. Cienc Rural 2000; 30(1): 187194. http://dx.doi.org/10.1590/S0103-84782000000100030.

Grau HEG, Cunha Filho NA, Pappen FG, Farias NAR. Transplacental transmission of Anaplasma marginale in beef cattle chronically infected in southern Brazil. Rev Bras Parasitol Vet 2013; 22(2): 189-193. http://dx.doi.org/10.1590/S1984-29612013000200038. PMid:23856734.

Guerrero FD, Lovis L, Martins JR. Acaricide resistance mechanisms in Rhipicephalus (Boophilus) microplus. Rev Bras Parasitol Vet 2012; 21(1): 1-6. http://dx.doi.org/10.1590/S1984-29612012000100002. PMid:22534937.

Klafke G, Webster A, Dall Agnol B, Pradel E, Silva J, de La Canal LH, et al. Multiple resistance to acaricides in field populations of Rhipicephalus microplus from Rio Grande do sul state, Southern Brazil. Ticks Tick Borne Dis 2017; 8(1): 73-80. http://dx.doi. org/10.1016/j.ttbdis.2016.09.019. PMid:27717758.

Kuttler KL, Johnson LW. Chemoprophylactic activity of imidocarb, diminazene and oxytetracycline againts Babesia bovis and $B$. bigemina. Vet Parasitol 1986; 21(2): 107-118. http://dx.doi.org/10.1016/0304-4017(86)90151-2. PMid:3739203.

Lau AOT, Cereceres K, Palmer GH, Fretwell DL, Pedroni MJ, Mosqueda J, et al. Genotypic diversity of merozoite surface antigen 1 of Babesia bovis within an endemic population. Mol Biochem Parasitol 2010; 172(2): 107-112. http://dx.doi.org/10.1016/j. molbiopara.2010.03.017. PMid:20371255.

Martins JR, Evans DE, Ceresér VH, Corrêa BL. Partial Strategic Tick Control within a Herd of European Breed Cattle in the State of Rio Grande do Sul, Southern Brazil. Exp Appl Acarol 2002; 27(3):241-251. http://dx.doi.org/10.1023/A:1021656927165. PMid:12593589.

ReckJ, Klafke GM, Webster A, Dall'Agnol B, Scheffer R, Souza UA, et al. First report of fluazuron resistance in Rhipicephalus microplus A field tick population resistant to six classes of acaricides. Vet Parasitol 2014; 201(1-2): 128-136. http://dx.doi.org/10.1016/j. vetpar.2014.01.012. PMid:24560364.

Schild AL, Ruas JL, Farias NA, Grecco FB, Soares MP. Aspectos epidemiológicos de um surto de babesiose cerebral em bovinos em zona livre de carrapato. Cienc Rural 2008; 38(9): 2646-2649. http://dx.doi.org/10.1590/S0103-84782008000900041.

Souza AP, Gonzales JC, Ramos Cl, Paloschi CG, Moraes AN. Variação sazonal de Boophilus microplus no Planalto Catarinense. Pesq Agropec Bras 1988; 23(6): 627-630.

Souza FAL, Liarte ASC, Castro KNC, Beserra EEA, Bernardi JCM, Sousa GV, et al. Dynamics of natural infection by Babesia bovis and Babesia bigemina in dairy cattle from an enzootic instability area in Northeastern Brazil. Rev Bras Parasitol Vet 2018; 27(1): 3-7. http://dx.doi.org/10.1590/s1984-29612018008. PMid:29641801. 
Suarez CE, Noh S. Emerging perspectives in the research of bovine babesiosis and anaplasmosis. Vet Parasitol 2011; 180(1-2): 109-125. http://dx.doi.org/10.1016/j.vetpar.2011.05.032. PMid:21684084.

Veiga LPHN, Souza AP, Bellato V, Sartor AA, Nunes APO, Cardoso HM. Resistance to cypermethrin and amitraz in Rhipicephalus (Boophilus) microplus on the Santa Catarina Plateau, Brazil. Rev Bras Parasitol Vet 2012; 21(2): 133-136. http://dx.doi.org/10.1590/ S1984-29612012000200011. PMid:22832753.

Vial HJ, Gorenflot A. Chemotherapy against babesiosis. Vet Parasitol 2006; 138(1-2): 147-160. http://dx.doi.org/10.1016/j. vetpar.2006.01.048. PMid:16504402.

Vieira MIB, Leite RC, Martins JR, Sacco MAS, Silva JGC. Resposta imune humoral contra Anaplasma marginale (Theiler, 1910) em bovinos submetidos a distintas estratégias de controle do carrapato vetor Boophilus microplus (Canestrini, 1887). Rev Bras Parasitol Vet 2002; 11(2): 71-76. 